\title{
NEW POLITICS, OLD PARADIGMS: URBAN \\ ENVIRONMENTALISM AND THE RESHAPING OF NEW DELHI
}

SOMNATH BATABYAL

\begin{abstract}
Taking two media-led environmental campaigns in India's capital, New Delhi, as case studies, this paper argues that Climate Change discourse has followed the patterns of development politics. While globalisation and economic shifts have altered the North/ South power dynamics since the twentieth century, the post development age has given rise to a transnational middle class that seeks to reemploy similar hegemonic paradigms and shape the world in its terms. This class has replaced the notional North; the world's poor replaces the notional South. This transnational middle class, the case studies highlights, moulds the environmental discourse in the public sphere to suit their own imaginations of urban space and the mainstream media is an active partner in this articulation.
\end{abstract}

\section{Introduction}

Within ten years of the Brundtland report, ${ }^{1}$ concerns around the environment, which had lurked for decades in the fringes of political discourse, entered the mainstream. Today, in both the global North and South, environmental rhetoric is built into political campaigns. It competes for attention with every other governmental concern, internationally and within nation states: issues of economic growth, development, poverty alleviation or even defence strategies. As the Tories in the UK are compelled to promise the 'greenest government ever', ${ }^{2}$ and Obama marked his 2008 victory speech as 'the moment when

${ }^{1}$ Known also as 'Our Common Future', the 1987 Brundtland Report published the findings of the Brundtland commission, an organisation commissioned by the UN secretary general in 1983 to raise awareness of the need for sustainable development and encourage nations to pursue united sustainable policies.

2 David Cameron's speech to civil servants at the Department of Energy and Climate Change, May 14, 2010. 
the rise of the oceans began to slow's so in India in battles between indigenous land owners in mineral-rich areas of Orissa and corporate entities like Vedanta, the courts are forced to legislate against indiscriminate mining. Brazil, like several other countries of Africa, use their land resources as a bargaining tool in international diplomacy making Northern countries compensate her for not denuding the rainforest cover. Environment has replaced Development as the overarching paradigm of 21st century politics.

This essay, however, seeks to culturally situate present day environmental discourse and show it as a continuation of the development politics that emerged in the middle of the last century. It argues that despite a shifting of the goalposts - climate change instead of hunger or forest degradation instead of abject poverty-the rules essentially remain the same: the powerful decide, the marginalised negotiate, albeit with some crucial differences.

Towards the end of the last century, development policies, with their focus on comparative equity and the forces of globalisation gave rise to a new 'transnational class of winners', ${ }^{4}$ educated cosmopolitan people who share the same aspirations whether they live in New York or New Delhi. According to Sachs, their proportion today is roughly equal in both the global South and North. ${ }^{5}$ With increased acceleration, this essay claims, these global citizens have started to impose their imagination on their habitation, especially cities, ignoring other claimants, their desires and needs. By moulding discourses in the public sphere through the use of media, especially mainstream, this new class has managed to pursue its own agenda, presenting it as 'common sense', similar to the economic

${ }^{3}$ Barack Obama’s election victory speech, November 4, 2008, Grant Park, Chicago, Illinois.

${ }^{4}$ Sachs, Wolfgang, "Preface to the New Edition," in The Development Dictionary: Knowledge as Power, ed. Wolfgang Sachs (London, New York: Zed Books, 2010), viii. The term is used by Sachs to refer to a new global middle class. This essay understands that to use the term uncritically, and for people across the globe, is problematic. Even in the Indian context, defining the middle class as a single set of people, is not without its critics. For more on this, see: Lakha, Salim, "The State, Globalisation and Indian MiddleClass Identity," in Culture and Privilege in Capitalist Asia, edited by Michael Pinches (London: Routledge, 1999), 251-74; and Deshpande, Satish, Contemporary India: A Sociological View (New Delhi: Penguin, 2003).

${ }^{5}$ Sachs, "Preface to the New Edition." 
model of development which too has been perceived as the only possible alternative. $^{6}$

Writing on New Delhi, where the two case studies are based, sociologist Amita Baviskar states:

The dream of inhabiting a world-class city, enjoying a lifestyle of convenience and comfort, is fuelled by real-estate firms, manufacturers and retailers of consumer durables, the entertainment and hospitality industries, and, most of all, the media. It is the expansion of this corporate capital in India that provides the context in which urban projects are imagined and pursued. $^{\text {? }}$

The first case study we examine, the Clean Air Campaign was launched in the mid-nineties. The Bus Rapid Transport (BRT) system, our second case study, was launched as a pilot project in April 2008. Both campaigns sought to reduce vehicular pollution in New Delhi but were divergently received by the media, which favoured the former and panned the latter. Critiquing the media representations around the campaigns, this essay will conclude that environmental concerns and their representations have been skewed by a powerful media, essentially middle class in its orientation, which has proved itself a most handy weapon for the globalised re-imagination of our cities.

In trying to understand a global trend, it seems appropriate to situate the case studies in India, integral to the "resurgence" of the Global South and a key member of the BRICS block. ${ }^{8}$ This should help to contextualise how the more affluent Southern countries are shaping their urban environment and what the socio-political implications of this engineering are.

\section{Methodology}

The focal point of this essay, Delhi's media, arises out of a personal involvement of the author who was both a journalist in the city for over a decade and is today a citizen concerned about the directions the metropolis is taking. This research, therefore, owes a particular debt to

\footnotetext{
${ }^{6}$ Esteva, Gustavo, “Development," in The Development Dictionary: Knowledge as Power, ed. Wolfgang Sachs, 1-23 (London, New York: Zed Books, 2010).

${ }^{7}$ Baviskar, Amita, "Between Violence and Desire: Space, Power and Identity in the Making of Metropolitan Delhi,” International Social Science Journal 55.15 (2004): 89.

${ }^{8}$ The BRICS countries include Brazil, Russia, India, China and the latest arrival, South Africa.
} 
the standpoint theorists who helped develop means of constructing episteme that resonates intensely with the experiential. ${ }^{9}$ Though standpoint theory has been critiqued for being insufficiently personal, the writer found that it helped to explain "why, I, the articulating academic, find a certain issue of value to explore but more importantly, how my subjectivity resonates with and through the subject matter as I analyse it” ${ }^{10}$ The choice of subject matter, the entry into the research and later analysis of the empirical evidence are influenced by this.

This personal interest is critically augmented with fieldwork in Delhi that includes a year-long ethnographic study of the Centre for Science and Environment (CSE), a prestigious knowledge-based NGO in New Delhi lobbying for environmental policies and one of the chief architects of the Clean Air Campaign. In-depth interviews were conducted with journalists, environmental campaigners and city planners, some of which find direct mention in this paper but all of which helped frame the author's ideas and thoughts. The paper also makes extensive use of secondary source material that ranges from critiques of development to political ecology and literature and media reports on cityscapes, which focus on Delhi. Besides these, the paper also makes use of the writer's previous ethnographic work conducted in India focusing on the media and its middle class articulations. ${ }^{11}$

Theoretically, this paper relies on one of last century's most seminal thinkers, Michel Foucault. Foucault has changed our perceptions of knowledge, linking it intrinsically with power (power/ knowledge complex) through discourse. ${ }^{12}$ Foucault has argued that discourse constructs the topic, that "[d]iscourse is a group of statements which provide a language for talking about [...] a particular topic at a particular historical moment" ${ }^{13}$ The study of discourses includes the rules, which prescribe certain ways of talking about some topics and excluding others

\footnotetext{
${ }^{9}$ See Harding, Sandra, The Feminist Standpoint Theory Reader: Intellectual and Political Controversies (New York: Routledge, 2003).

10 Sreberny, Annabelle, "Globalisation and Me," in In Search of Boundaries: Communication, Nation States and Cultural Identities, ed. Joseph Chan and Bryce T. Mcintyre (Westport, London: Ablex, 2002), 294.

${ }^{11}$ See Batabyal, Somnath, Making News in India: Star News and Star Ananda (New Delhi: Routledge, 2012).

${ }^{12}$ See Foucault, Michel, The Order of Things: An Archaeology of the Human Sciences (London: Tavistock, 1972).

${ }^{13}$ Hall, Stuart, Representation: Cultural Representations and Signifying Practices (London: Sage, 1997), 44.
} 
and how knowledge about a topic acquires authority, a sense of embodying the 'truth' about it. This knowledge linked to power not only assumes the authority of 'the truth' but also has the power to make itself true, "not the 'Truth' of knowledge in the absolute sense but of a discursive formation sustaining a regime of truth". ${ }^{14}$ Calling into question the overall category of 'reality', Foucault demystifies the 'regimes of truth', (media, governments, agencies, world views, etc.) which claim that there is a singular version of reality that can be identified. This paper, through case studies, seeks to demystify the present day discourse of 'environmentalism' in urban spaces, arguing instead that it is a construct of middle class urban citizens, spearheaded in the public sphere by an activist media, middle class in its construct.

\section{The Story of Development}

Development as we know it - a continuous drive towards more and more economic prosperity-was literally invented post Second World War and announced on June 9, 1949 by US President Truman..$^{15}$

We must embark on a bold new program for making the benefits of our scientific advances and industrial progress available for the improvement and growth of underdeveloped areas.

The old imperialism—exploitation for foreign profit—has no place in our plans. What we envisage is a program of development based on the concepts of democratic fair dealing. ${ }^{16}$

No longer will the former colonies be exploited, they will receive 'the benefits of our scientific advances and industrial progress'-in other worlds, be helped to become more like 'us'-in this case, the United States. In this speech, Truman sets up the American lifestyle as the benchmark of aspirations, a phenomenon that is backed by Hollywood films depicting country ranches and farms, fast cars and trawlers, washing machines and dishwashers, and later through multi-million dollar advertisement campaigns and multinational brands as they enter the 'underdeveloped' world.

\footnotetext{
${ }^{14}$ Hall, Representation, 49-50.

${ }^{15}$ Esteva, "Development," 1.

${ }^{16}$ Truman, Harry S., "Inaugural Address," published by Gerhard Peters and John T. Woolley, The American Presidency Project, January 20, 1949, accessed December 3, 2012. http://www.presidency.ucsb.edu/ws/?pid=13282.
} 
Development has its fair share of critics and cheerleaders and it is not the purpose of this essay to weigh in for either. But what the style of development championed by Truman definitely did was to speed up the extraction of earth's precious and limited resources. "It is the legacy of the twentieth century," Wolfgang Sachs points out, "that the desires of nations for a better tomorrow are predominantly directed towards development as growth. However, the multifaceted crisis of the biosphere turns this legacy into a tragic liability." ${ }^{17}$ The last fifty years have seen an alarming depletion in ground water levels, greedy exploitation of minerals, denuding of forest cover and a hole in the ozone layer; the human race is at the brink of a catastrophe from which there might be no recovery.

At this point, we arrive at one of the central dilemmas of the development ethos. The ethics of development is based on a founding principle: the idea of 'comparative equity', that the earth's resources be divided and shared in equal measure by all. Into the second decade of the 21st century, there is almost no contesting that the earth has limited resources and a major share of it has been used up by the rich nations. Indeed, no more industrial revolutions can take place; the earth simply doesn't have enough in its coffers. If all of the world were suddenly to reach a Western level of living standards, we would need 'five or six planets' to take the load. ${ }^{18}$ There can be no relative equity.

Yet, the common refrain heard at every climate summit from every Southern corner is their 'right to develop'. Poor countries contend, and justly, that they must be given their due share of the resources and the atmosphere to develop.

The longing for greater justice on the part of the South is one reason for the persistence of the development creed - even if, in this century, neither the planet nor the people of the world can any longer afford its predominance. $^{19}$

The pursuit of 'economic justice', the realignment of the financial world and the insidious forces of globalisation have helped the rise of the Southern powers; China, Brazil and India being at the forefront of a GDP-driven revolution.

\footnotetext{
${ }^{17}$ Sachs, “Preface,” x.

${ }^{18}$ Ibid., xvii.

${ }^{19}$ Ibid., ix.
} 
For them, it is as if President Truman's promise at the birth of the development period in 1949-that poor nations would catch up with the rich-had finally come true. [...]

As a result of this shift, development came to mean the formation of a global middle class alongside the spread of the transnational economic complex, rather than a national middle class alongside the integration of a national economy. Seen from this perspective, it comes as no surprise that the age of globalisation has produced a transnational class of winners. ${ }^{20}$

Today Indian tourists book out Thomas Cook charter flights to Paris and Beijing's cheap workforce keeps the global consumer industry afloat. But it is problematic to celebrate this as a 'revival of the South', when it represents a shift and not an end to inequality. This, as Sachs and Esteva argue, is the legacy of development policies which have espoused a notion of comparative equity - where nations should have a fair share of the world's wealth — and not absolute equity—which recognises the individual's right to a fair share.

Indeed, southern countries have managed to raise their economic profile significantly, but development policies, falling short of absolute justice, has left more than half of the world's population still without the right of access to food, shelter, clean air, water and basic health care. In Sach's stark words:

The globally oriented middle classes, although they push for development in the name of greater equality, largely disregard the plight of the poor. [...]. In just about all newly industrialising countries, social polarisation has been on the rise along with growth rates over the past thirty years. ${ }^{21}$

The earlier victims of inequality were the poor nations; today when money and influence are turning increasingly transnational, the dominated are the global poor. As Esteva explains in the same volume, the poor are not simply left poor, their means of resistance to hegemony is simultaneously undermined:

Redevelopment implies the economic colonisation of the so called informal sector. In the name of modernisation and under the banner of the war on poverty-pitting as always the waged against the poor, not a war on poverty itself-redeveloping the south involves launching the last and definitive assault against organised resistance to development and economy..$^{22}$

\footnotetext{
${ }^{20}$ Sachs, "Preface,” vii.

${ }^{21}$ Ibid., $\mathrm{x}$.

${ }^{22}$ Esteva, “Development," 13.
} 
Before this essay moves to New Delhi and the two particular case studies mentioned above, it is important to frame, if briefly the 'emergence' of India as an economic power and along with it, the rise of its media which pushes an unashamedly middle-class, urban agenda.

\section{India and its New Middle Class}

India is in the news; or rather, the country is making the news. Be it an Indian billionaire buying a British automobile or steel company or reports of Hollywood celebrities descending on a Bollywood theme wedding in Mumbai, the framing of 'India' from a poverty stricken nation of famine, drought and hunger has changed drastically. Even the abject poverty of a Slumdog Millionaire ${ }^{23}$ is glamourised.

It is by now accepted that the liberalising of the economy in the early 1990's was a watershed moment which unleashed the growth potential of a slumbering country shackled by protective regimes. But even before the opening of the markets, between 1980 and 1989, India had witnessed a 47.5 per cent rise in consumption expenditure. ${ }^{24}$ The much-vaunted Indian middle class, touted today as the world's largest had become tired of molly-coddled national brands, afraid of competition and producing inferior quality goods. A whole generation of consumers were waiting in the wings when the trade barriers were pulled down and Pepsi, Coca Cola, Nike and Adidas announced their arrival.

As the decade progressed, this new and confident middle class, animated by the vision of setting India on a liberated path of progress and economic prominence on the world stage,

assumed for themselves the role of the makers of the nation in new ways. In the emerging middle class political vision, the nation is a community of citizens who are enfranchised by freedom of choice, consumption and material gratification and a lifestyle of enjoyment and pleasure. ${ }^{25}$

Fernades notes that

${ }^{23}$ The 2008 Danny Boyle film won 8 Oscars.

${ }^{24}$ Dubey, Salman, "The Middle Class," in India Briefing, ed. Leonard Gordon and Philip Oldenberg (Boulder, London: Westview Press, 1992), 150.

${ }^{25}$ Chakravorty, Rangan, and Nandini Gooptu, "Imagi-Nation: The Media, Nation and Politics in Contemporary India,” in Cultural Encounters: Representing Otherness, ed. Elisabeth Hallam and Brian V. Street (London: Routledge, 2000), 91. 
production of the new Indian middle class parallels comparative trends in the construction of the 'new rich' as a social group that is the prime beneficiary of globalisation in contemporary Asia. The construction of such a category, in effect, marks the potential benefits of globalisation for emerging market-oriented contexts in nations such as India. ${ }^{26}$

However, the discourse of economic prosperity aside, millions of Indians remain desperately poor.

We [India] are a nation of nearly a billion people. In development terms we rank number 138 out of the 175 countries listed in the UNDP's Human Development Index. More than four hundred million lack even basic sanitation, and over two hundred million have no safe drinking water. ${ }^{27}$

How is a country where nearly 500 million live below the poverty line able to frame itself as an economic powerhouse? The average Indian family today consumes 100 kilograms less food than it did in 1991 when the process of economic reforms started to kick in. Incidents of farmers, unable to pay back loans, committing suicide have become so regular that they are relegated to the inside pages of local dailies. Female infanticide, famines and droughts, appalling health services and lack of educational infrastructure are glossed over for celebrity weddings and the arrival of Formula 1 events in New Delhi's suburbs, a trick which writer/ activist Arundhati Roy in a 2012 BBC interview termed as a "false voice, a lie". ${ }^{28}$

Roy's comment on India's global image of a thriving democracy with a high growth output being manufactured by the media is crucial. It is often the media that becomes the "primary site for the exposition of different social and political discourses [...]" ${ }^{29}$ and the discourse of India's well-being has been carried on the shoulders of a pliant media. Here we reach the crux of this essay: how a burgeoning, global middle class shapes their environments to their liking, ignoring other possibilities and imaginations and how the media becomes a handy tool in this imposition of will by framing bourgeois desires as 'common

\footnotetext{
${ }^{26}$ Fernandes, Leela, "The Politics of Forgetting: Class Politics, State Power and the Restructuring of Urban Space in India," in Urban Studies 41.12 (2004): 2415.

${ }^{27}$ Roy, Arundhati, "Introduction,” in India: A Mosaic, ed. R. Silvers and B. Epstein (New York: New York Review of Books, 2000), xxiv.

${ }^{28}$ BBC News, "Author Arundhati Roy: India's Economic Success a 'Lie', last modified June 2, 2011, accessed May 23, 2011. www.bbc.co.uk/news/world-south-asia13624077.

${ }^{29}$ Chakravorty, and Gooptu, “Imagi-Nation,” 93.
} 
sense' and reflecting a world of particular aspirations. If, in the last century, it was the north reflecting a way of life as the only possibility of development, today it is the affluent class in both halves of the globe who shape our cities according to their desires and imaginations.

To understand this collusion of media and middle class desire in the Indian context, it is important to note that the upward curve in the economy, the liberalising of the markets and a sudden unprecedented growth in the media industry, especially television, happened simultaneously.

Melissa Butcher states in the preface to her book, Transnational Television, Cultural identity and Change: When Star Came to India:

India was undergoing a sea-change as the impact of the state's deregulation began to visibly kick in at deeper and deeper levels within the country. The media landscape simultaneously embodied and reflected those changes. ${ }^{30}$

Embodied in terms of spectacular growth: by 2006, the industry was estimated to be worth more than Rs 185 billion (approximately £230 million), a dramatic turnaround from its humble beginnings in 1959 as an educational project sponsored by the state. ${ }^{31}$ Government-run Doordarshan, the only channel on Indian airwaves until the early 1990s, has now been eclipsed by an extraordinary explosion of private channels. With 360 channels currently on air, and 160 waiting for the government's permission to follow suit, the television viewer in India has more choice than anywhere else in the world. More than a hundred million households in India now own at least one television set. Seventy million of them are connected to cable or satellite TV. At their fingertips lie choices galore: movie channels, music channels, television soap operas and news broadcasts. CNN and BBC, the Rupert Murdoch-owned Star TV bouquet of channels, international sports channels and home grown Zee Television all vie for their attention.

The media reflected the economic changes by screening more and more glitz and glamour of an India on the rise. The black and white days have been replaced with gloss, gossip and money. As Hartley argues, news is "the sense-making practice of modernity"; it is an important medium through which we understand ourselves and the world around

\footnotetext{
${ }^{30}$ Butcher, Melissa, Transnational Television, Cultural Identity and Change: When Star Came to India (New Delhi: Sage, 2003), 9.

${ }^{31}$ Kohli, Vineeta, The Indian Media Business (New Delhi: Sage, 2006), 62.
} 
us; who we are, what we are, our collective likes and dislikes. ${ }^{32}$ Television created India in its own image: rich, booming and ready to compete on the world stage.

Within the medium of television, the news genre saw the most spectacular growth; prompting Thussu to ask “is India the world's biggest TV news bazaar?”33 From just one news channel in 1998, today India has close to sixty 24-hour news channels spread across the country, most of which are "national, but many international in reach, some cater[ing] to the regional markets." ${ }_{34}$

This essay argues that an inherently undemocratic, advertisementdriven news media combined with a vocal middle class combined to give shape to our cities and our priorities. This has changed the nature of environmental movements and their reportage in India from an 'environmentalism of the poor' to a 'bourgeoise environmentalism' ${ }^{35}$. Change of course presupposes history and this post-liberalisation phenomenon must therefore be understood in the light of what went on in the previous decades in Indian environmental movements and in its media.

\section{Indian Media and Environmental Movements: A Very Brief Summary}

The origins of the press in India are rooted in the country's Independence movement and it was therefore closely aligned with the main political party, the Congress. After the end of the colonial rule, as the Congress came to power under Prime Minister Jawaharlal Nehru, the press easily fell into the role of backing the state in the task if nationbuilding. This cosy relationship continued till the 1970s. In 1974, when Nehru's daughter and then Prime Minister Indira Gandhi declared a state of Emergency and curtailed constitutional freedom including gagging the press, the partnership ended. A new era of politically independent journalism was to emerge.

The Indian environmental movement that emerged around the same time was a direct result of the economic development prescribed by

\footnotetext{
${ }^{32}$ Hartley, John, Popular Reality: Journalism, Modernity, Popular Culture (London: Arnold, 1996), 32.

${ }^{33}$ Thussu, Daya, News as Entertainment: The Rise of Global Infotainment (London: Sage, 2007), 96.

${ }^{34}$ Ibid., 96-97.

${ }^{35}$ The expression is coined in: Baviskar, "Between Violence and Desire.”
} 
Nehruvian socialism. Within two decades of independence, "development had quickly been equated to channelizing the nation's resources towards a narrow elite of omnivores-powerful landowners and urban people in the organised industries and service sectors. ${ }^{{ }^{36}}$

The environmental movement in the country emerged in response to this large-scale degradation of forest and agricultural soil, pollution of rivers and usurpation of land rights. Writing on the social attributes of the environmental movements, Karan states that

(e)ven with limited resources the environmental movements have initiated a new political struggle for safeguarding the interests of the poor and the marginalized, among whom are women, tribal groups, and peasants. ${ }^{37}$

"Many of these groups," Anil Agarwal notes, "are old and their main concern is either civil rights, rural development, tribal welfare, appropriate technology, primary health care, or science demystification. ${ }^{{ }^{38}}$ The 'red' and the 'green' were thus part of the same movement, each, with its own concerns, written into the other.

One of the earliest manifestations of the environmental movement was in "March 1974 when women of the Garhwal Himalaya hugged ash trees to save them from the axe of contractor's men, launching the Chipko Andolan. ${ }^{39}$ Karan enumerates a number of other prominent agitations caused by the lopsided developmental programmes in post Independence India:

Save the Bhagirathi and Stop Tehri project committee in Uttar Pradesh; Save the Narmada Movement (Narmada Bachao Andolan) in Madhya Pradesh and Gujarat; youth organizations and tribal people in the Gandhamardan Hills whose survival is directly threatened by development of bauxite deposits; the opposition to the Baliapal and Bhogarai test range in Orissa, the Appiko Movement in the Western Ghats; groups opposing the Kaiga nuclear power plant in Karnataka; the campaign against the Silent Valley project; the Rural Women’s Advancement Society (Gramin

\footnotetext{
${ }^{36}$ Gadgil, Madhav, Ecological Journeys (New Delhi: Orient Blackswan, 2005), 27.

${ }^{37}$ Karan, Pradyumna, "Environmental Movements in India," Frontier Thinking in Sustainable Development and Human Well Being 84 (1994): 32.

${ }^{38}$ Agarwal, Anil, “An Indian Environmentalist's Credo," in Social Ecology, ed. Ramachandra Guha (Berkeley: Oxford University Press, 1994), 346.

${ }^{39}$ Gadgil, Ecological Journeys, 26. Chipko Andalan was a non-violent movement protesting deforestation in Uttarkhand.
} 
Mahila Shramik Unnayam Samiti), formed to reclaim waste land in Bankura district; and the opposition to the Gumti Dam in Tripura. ${ }^{40}$

One of the unifying themes of these movements was that they were played out in remote parts of the country, away from the eyes of the urban Indian. Yet movements like Chipko Andolan or NBA ${ }^{41}$ attained iconic status, not only within India but globally, as showcase examples of grassroots movements. Without a doubt, the country's media, especially its newspapers played a prominent role in keeping these movements alive in urban consciousness. In his 1994 work, Social Ecology, Ramachandra Guha duly notes that

[...] there has been a spectacular growth in public consciousness about the forms of environmental degradation in India. With an amazing but welcome rapidity, this awareness is being translated [...] into substantial media coverage $[\ldots]$ Continuous and sustained press coverage ensured that most of urban India, if not involved with the movements, was largely sympathetic towards this "environmentalism of the poor. ${ }^{42}$

A nascent environmental movement found strong support from a media emerging out of state shadow and taking its first dissident steps. What changed and how?

To answer this question, the essay now examines two case studies of vehicular pollution in India's capital New Delhi and the media campaigns surrounding them. In analysing the campaigns, this essay uses the experiential, interviews, court and media reports.

\section{New Delhi and Indian Urban Environmentalism}

The National Capital Territory of Delhi became the capital of British India in 1919. At the time of Independence in 1947, its population was estimated to be 400,000 people.

\footnotetext{
${ }^{40}$ Karan, “Environmental Movements in India," 32.

${ }^{41}$ The Narmada Movement (Narmada Bachao Andolan) is a social movement campaigning against the Sardar Sarovar Dam construction in the Narmada river in Gujurat.

${ }^{42}$ Guha, Ramachandra, Social Ecology (Berkeley: Oxford University Press, 1994), 3.
} 
Between 1951 and 2001, the population of the NCT grew from 1.7 million to 13.8 million (Census of India), and about half of the population now has to live in informal settlements and shanties (jhuggis). ${ }^{43}$

Today 20 million are estimated to live in the metropolis with another three million strong-floating population that comes in everyday.

This exponential growth has led to varied struggles over the control of resources, especially over the use of land and water and increasingly over notions of 'beautification' and in efforts to 'clean up' the city and impose 'civic order'. The first of these battles, after the economic liberalisation of 1993, was over the right to clean air and this campaign, fought as much in courtrooms as in the front pages of newspapers, inadvertently charted the direction of urban environmentalism in India.

The beginnings of the campaign go back to 1985 when the environmental lawyer M.C. Mehta had filed a public interest litigation (PIL) against vehicular pollution in Delhi with the Supreme Court of India. This PIL was based on the constitutional obligation of the state to protect the health of its citizens, which case law implicitly extended to a right to a clean environment. In response to the PIL, the Court issued notices to the Union and Delhi government. The response was a Pollution Under Control Drive launched by the government in the early 1990's, which meant that owners were to get their vehicles tested at filling stations. Lax norms and rampant corruption in issuance of certificates however meant little overall improvement in Delhi's air quality. By the mid nineties, Delhi's air quality deteriorated further and visibly. Black, acrid smoke hung in the air, buses and trucks belched out poisonous fumes and the addition of more and more diesel cars to the city's congested roads, a gift of economic liberalisation, added to the woes.

Somewhere around the end of 1997, a full-page advertisement was carried out in the Times of India (TOI) by a then little known NGO, the Centre for Science and Environment. The advert screamed "51,779 Dead by Breathing." ${ }^{4}$

The CSE campaign, as their late director Anil Agarwal put it, "began without a premeditated design." ${ }^{45}$ It was in the summer of 1995, while

\footnotetext{
${ }^{43}$ Delhi Development Authority, 2000, cited in Sivam, Alpana, "Housing Supply in Delhi," Cities 20 (2003), 135.

${ }^{44}$ Agarwal, Anil et al., The Leap Frog Factor: Clearing the Air in Asian Cities (New Delhi: Centre for Science and Environment: 2006), 5.

${ }^{45}$ Agarwal et al., The Leap Frog Factor, 5.
} 
waiting to get the tail pipe of his car checked for pollution at a petrol pump that Agarwal felt vehicle owners were being unnecessarily penalised for a problem that did not start with them. The CSE launched an investigation into air pollution in our cities which was published in the public domain as Slow Murder in November 1996. It brought to light not only the wide-ranging factors, which had contributed to the "pollution mud pie", but also the politician/ auto industry nexus which turned a blind eye to the problem.

Just after the publication of Slow Murder, on November 18th, 1996, the Supreme Court of India joined hands with the activists and issued a suo motto notice to the Delhi Government to submit an action plan to control air pollution in the city in November 1996, merging the notice with M.C. Mehta's PIL and on which little action had been taken till now. To put pressure on the government to take action, the CSE also decided to launch a public interest campaign called the "Right to Clean Air" around the same time. And this is where the campaign came to life. Through advertisements in newspapers and lobbying journalists who were only too eager to comply, a forceful campaign was built up.

Anumita Roychowdhury, who heads the CSE's Air Pollution division, said in an interview:

"It was the Clean Air Campaign which marked a definite shift in the CSE policy. We became an advocacy group, a lobbying force for change. We understood how to use the media to pressurise the state through this campaign. Our later campaigns were shaped through this understanding." 46

The Union Ministry of Environment and Forest, forced into action by a relentless media campaign, formed the Environment Pollution (Prevention and Control) Authority (EPCA) in January 1998, which would be responsible for the National Capital Region (NCR). It was headed by senior bureaucrat, Bhure Lal, environmental activist Anil Agarwal, the then transport commissioner of Delhi, Kiran Dhingra and Jagdish Khattar, former executive director (marketing and sales) of Maruti Udyog Ltd., who represented the automobile industry. The EPCA, therefore, saw for the first time the coming together of the state, activists and the corporate sector to give a definite shape to Delhi's physical environments.

\footnotetext{
${ }^{46}$ Interview conducted with the author on November 6, 2010 at the CSE office in New Delhi.
} 
Based on the recommendations of the EPCA, a comprehensive court order was issued in July 1998 that included the elimination of leaded petrol, the replacement of old autorickshaws (motorised three-wheel passenger vehicles) and taxis, the augmentation of the bus fleet in the city to 10,000 from 6600 and, most strikingly, the conversion of all buses, autorickshaws, and taxis from diesel and petrol to compressed natural gas (CNG). After some back and forth on the CNG issue, the final phase-out period for diesel buses was from April to November 2002. Furthermore, new emission standards for private vehicles (BharatI and Bharat-II based on European standards) were introduced, and the driving of (diesel) trucks was banned during daytime in the NCT. ${ }^{47}$

The court order was one thing, implementation was another. "The orders could only be implemented if there was political will; unfortunately there was none. Politicians were not convinced about the problem.” ${ }^{48}$ The struggle to implement the court's orders, given the government's prevarication, was however dealt with severely by an activist media. For five years, the mainstream media kept pressure on the government along with the civil society and environmental activists. When the then Health Minister Harsh Vardhan claimed that air pollution was not a serious health problem, the media hounded him and forced him to retract. The Lieutenant Governor's remark at a press conference in late 1997 that Delhi pollution was simply "dust particles", ${ }^{49}$ sparked off a media outcry. Public opinion, moulded by an activist press and judiciary, forced the Delhi government's hand and by mid 2003 the Clean Air Campaign launched by CSE had achieved most of its objectives. In the next few months, the air quality in Delhi improved visibly.

Within five years of the Supreme Court ruling however, the gains from the campaign seemed nullified. The almost double digit growth rates of the economy and easily available loan schemes meant a spurt in ownership of private vehicles and by August 2008, the average total suspended particulate (TSP) level in Delhi was 378 micrograms per cubic meter-approximately five times the World Health Organisation's (WHO) annual average standard. With approximately a thousand private vehicles being added everyday in Delhi, vehicular pollution was at an all time high.

\footnotetext{
${ }^{47}$ Veron, Rene, "Remaking Urban Environments: The Political Ecology of Air Pollution in Delhi," Environment and Planning A 38.11 (2006): 2099.

${ }^{48}$ Agarwal et al., The Leap Frog Factor, 7.

${ }^{49}$ Ibid., 8.
} 
It is in this context, the mainstream media's hostile reception to the Delhi government sponsored BRT or Bus Rapid Transport project in 2008 and the ensuing public outcry is surprising. Even before the project was fully operational, the media backlash had begun. Television channels, newspapers, even magazine reports, decried the initiative. So much so that despite the fact that more commuters were moving at a quicker pace in the BRT corridor, further expansion of the project was shelved by the government.

Simply put, the BRT is a dedicated corridor for the public buses, which move more than 60 per cent of the daily commuters in Delhi. Despite the fact that they carry more people, the road space given to buses is disproportionately less than to private vehicles. By dedicating bus only corridors, travel time for the commuters was meant to be reduced and the use of private transport discouraged thereby reducing vehicular pollution.

Even if we leave aside for a moment the issue of clean air, the benefits of public transport in a metropolis like Delhi seem indisputable. The physical geography of India's capital has considerably changed in the past two decades, especially since the beginning of this century. Roads in Delhi increased from 22,487km in 1991 to $31,183 \mathrm{~km}$ in 2008, an increase of 17 per cent. Flyovers and underpasses have come up and roads now account for nearly 21 per cent of Delhi's surface area, leaving little scope for further expansion. Yet, in the same period, the ownership of private vehicles has gone up more than 200 per cent and Delhi now has over 6.5 million vehicles, with approximately a thousand cars being added everyday. As cars owners supplement their fleet, four-wheelers replace two-wheelers and cyclists graduate to scooters and motorcycles, it is evident that no amount of road construction can keep pace with the pace of vehicle ownership.

The aims of the Clean Air Campaign and the BRT were similar in that both wanted to improve the cityscape and the health of the citizens by cleaning up the toxic nature of Delhi's air quality. One sought to do this by ushering in clean fuel and the other by incentivising the use of public transport. Yet both campaigns received markedly contradictory responses. In the next section, through interviews with journalists and city planners and analysis of both the media led campaigns, the essay 
seeks to show how the bourgeoise "strategies of exclusion" force a singular imagination in the public sphere of the cityscape..$^{50}$

\section{Analysis}

The liberalisation process of the mid 1990s was, whichever side of the fence one sits on, a watershed moment, both for the economy and the wider socio-political sphere. Nowhere was this more marked than in the country's media where staid old Doordarshan ${ }^{51}$ was giving way to Star's Bold and Beautiful and newspaper wars were hotting up as Times of India and the Hindustan Times launched their one-upmanship campaigns to achieve dominance in the capital. But more importantly, the journalists - their aims, ambitions and desires for themselves-were changing. The particularities of the profession require a certain skill level, which in India, as in most other countries, is equated with the middle and more affluent classes. Media scholar Ginneken writes: "Most journalists are middle-class in social background, social position and social aspirations." ${ }^{52}$ In an interview, Debashish Mukerji, senior Associate Editor of the Hindustan Times, put it succinctly:

"We suddenly had journalists who were travelling regularly, some on meaningless junkets, some on stories. Closer-to-home destinations like Singapore and Hong Kong were getting to be a regular fare. These journalists, dazzled by what they saw, started imagining the same for their city. Judges travelled, petty officials travelled and the glamour of the West was brought home. Now they wanted the same in their city." 53

In the mid nineties, as the journalists started travelling, as Murdoch brought the 'dazzling' world of American television into Indian bedrooms, as the first multinational corporations started to take their baby steps on Delhi's soil, the air of the capital was dark. As journalist on a daily city beat in a newspaper, this writer and other reporters around him knew how bad the air quality was but did not know what to do about it. The environment was not a beat and no one reported much on it. The government-launched Pollution Under Control drive (PUC), which

\footnotetext{
${ }^{50}$ Baviskar, “Between Violence and Desire,” 16.

${ }^{51}$ This is a state-owned television channel.

${ }^{52}$ Ginneken, Jack van, Understanding Global News (London, Thousand Oaks, New Delhi: Sage, 1998), 71.

${ }^{53}$ Interview with the author, New Delhi, September 24, 2010.
} 
involved someone checking the exhaust of your car at petrol pumps, was assigned to the crime reporter to check for evasions. Journalists understood that things were bad but did not know whom to hold responsible, how to write the story. In a medium, which likes simplicity above all else, the subject matter was complicated.

The first of the Clean Air Campaign advertisement, the CSEsponsored "51,779 Dead by Breathing," in The Times of India, was a game changer. A simple narrative which linked air pollution to sickness and death and managed to bypass the complicated physics of harmful particulate matters in the air, their relationship to the petroleum and auto industries, the nexus between politicians and the transport lobby and so on, was picked up by the journalists and the media. The press community immediately got interested and headlines followed. Reporters understood through experience of being out on the streets that bad air was harming them, their families and their friends. The story easily became personal. And here perhaps lies the key to a campaign that sustained for over six years, from 1997 till 2003, itself a miracle given the media's attention span: the story was personal, personal to the middle class journalist and his/her audience.

K.S. Sachidananda Murthy, Resident Editor of the Malayala Manorama Group in Delhi said in an interview with the author:

"Of course the press is middle class with a middle class vision. We are so middle-class that we are also anti-super rich. We are happy when, say, the Delhi Development Authority (DDA) goes out to acquire land or the Noida Development Authority does so. We think we can get housing under their schemes, our readers can. But come Special Economic Zones ${ }^{54}$ we turn against even the top corporate houses indiscriminately, be it an Indian company like Reliance or a foreign entity like the Salim group in Nandigram. But yes, it is the middle class interest we have in our hearts and that is very closely linked to our reader profile. One must keep that in mind., 55

Murthy's link between the social status of the journalist and that of his/ her reader is important; he emphasises that middle class journalists writes for a middle class audience and the success and longevity of the

${ }^{54}$ A Special Economic Zone (SEZ) is a geographical region that has economic laws that are more liberal than the country's typical economic laws. Usually, the goal is an increase in foreign investment. In India, as the government has appropriated land for investment, several of these zones have turned into battlegrounds between peasants and the authorities.

${ }^{55}$ Interview with K. S. Sachidananda Murthy, September 28th, 2010, New Delhi. 
Clean Air Campaign were closely linked to this: a middle class reimagination of Delhi as a "world class city". ${ }^{56}$

Along with the air quality of Delhi therefore a few other things changed which perhaps CSE's initial campaign had not bargained for. The campaign definitely helped in making urban environmental issues a legitimate concern in the city's mainstream media. But in attempting to push environment from the fringes to the centre of political discourse via the media, it probably did not envisage that essentially middle class journalists writing for a largely middle class audience would throw aside the earlier 'pro poor' concerns of India's environmental movement.

As studies show, the poor had other, more immediate things to worry about than air pollution. While the media placed priority on clean air and beautification drives, it was "water supply and sanitation [that] formed the greatest environmental priorities for Delhi's poor inhabitants." In a comprehensive study done on Delhi's slums, inadequate and insufficient sanitation were found to be the most severe deficiency, while noise and air pollution are mentioned as merely "adding to the extremely poor conditions of environment." ${ }^{\text {57 }}$

Although Delhi's environmental policies centering on air quality have lessened exposure to environmental risks across socioeconomic classes, they have hardly addressed an environmental priority of the urban poor. I would argue that the intensity and effectiveness of environmental activism in the field of air pollution is reflective of a general middle-class bias, and that the larger (environmental) NGOs engaged in policy advocacy have paid little attention to the main environmental concerns of the urban poor. ${ }^{58}$

These concerns were however not the media's priority for Delhi, nor of the new kind of environmental awareness which was emerging in urban India. The 'environmentalism of the poor' vanished into the dustbins of history as an elite media and its readership sought to etch a 'bourgeois environmentalism' that privileged the concerns of the burgeoning middle class over any other.

Just a couple of years before the Clean Air Campaign was launched, academic Amita Baviskar wrote:

\footnotetext{
${ }^{56}$ Interview with K. S. Sachidananda Murthy, September 28th, 2010, New Delhi.

${ }^{57}$ Ali, Salim, Environmental Situations of Slums in Delhi, 2003, cited in Veron, "Remaking Urban Environments," 2101.

${ }^{58}$ Veron, "Remaking Urban Environments,” 2101.
} 
[T]hrough a series of judicial orders, the Supreme Court of India has initiated the closure of all polluting and nonconforming industries in the city, throwing out of work an estimated 2 million people employed in and around 98,000 industrial units. At the same time, the Delhi High Court has ordered the removal and relocation of all jhuggi squatter settlements ${ }^{59}$ on public lands, an order that will demolish the homes of more than 3 million people. In a city of 12 million people, the enormity of these changes is mind-boggling. ${ }^{60}$

What Baviskar perceives to be mind-boggling was nothing compared to what was to come.

Between 1990 and 2003, 51,461 houses were demolished in Delhi under 'slum clearance' schemes. Between 2004 and 2007 alone, however, at least 45,000 homes were demolished, and since the beginning of 2007, eviction notices have been served on at least three other large settlements. ${ }^{61}$

The fourth estate, with very minor exceptions, has been largely supportive of the drive.

It is in this light that one must look at the media campaign and furore over the BRT and the apparent public denouement of the scheme. Unlike the CNG, the BRT's public profile was doomed from the start. A residential colony of the city's influential journalists was situated close by and a host of them who make their way towards central Delhi for work every morning were inconvenienced. A senior editor in one of the city's biggest newspapers told this author that as his car was stuck in the traffic one morning, he decided to run a campaign against the corridor. Like the CNG campaign, it was also was personal. Other newspapers and television channels, especially in the English language, unequivocally panned the project. Even at its trial period in May 2008 (the height of summer is probably a bad time to start anything), the press coverage was unsparingly scathing. The project did not stand a chance.

"What the press missed," said Sam Miller of the BBC, "was that it was supposed to inconvenience cars. That was the whole point." ${ }^{62}$ In contrast to the Metro, which started in the poorer parts of the capital, Miller pointed out that the BRT suffered from being situated in the heart

${ }^{59}$ Illegal temporary homes.

${ }^{60}$ Baviskar, "Between Violence and Desire," 90.

${ }^{61}$ Bhan, Gautam, “'This is No Longer the City I Once Knew’: Evictions, the Urban Poor and the Right to the City in Millennial Delhi," Environment and Urbanisation 21 (2009): 127.

${ }^{62}$ Interview with Siddarth Pandey, October 4, 2010, New Delhi. 
of the affluent South Delhi: "The Metro came up quietly. People got to know about it, then they wanted to have a day out on it. They got used to it. The BRT inconvenienced the powerful." ${ }^{33}$

In another interview, Siddarth Pandey, a senior journalist covering environment in New Delhi Television (NDTV), one of India's most reputed news television organisations, started laughing when asked if he had ever travelled by bus on the BRT corridor: "Are you joking? I am just trying to get to my office in the morning. The bosses will lynch me if I try a stunt like that and say I am taking the bus.” When asked how he knew, having never tried it, that the BRT was a disaster, he responded: "Well you should look at the cars stuck in the morning traffic. It is a long queue. I mean they [the government] should have tried something else.” ${ }^{\prime 4}$ When asked what sort of alternatives, no clear answer emerges.

Writing in environment magazine Down to Earth, Sunita Narain, Director of CSE writes "BRT is About Equity on the Road," stating that the logic of a bus corridor is irrefutable:

The bus moves more than 50 per cent of the city but does not get proportionate space. In the first stretch of the Delhi BRT corridor, over this last year, buses have doubled to 3,000-they now commute roughly 200,000 people each day. ${ }^{65}$

As Narain points out, the BRT "meant taking from a few and giving to many." ${ }^{{ }_{6} 6}$ But amongst these few were the powerful articulators of our reality, the journalists and their audience. Together they created a public opinion against the BRT that was so strong that the Delhi Chief Minister Sheila Dixit was worried that her re-election in 2009 was doomed. The BJP's chief ministerial candidate, Vijay Kumar Malhotra, taking advantage of the media outcry, promised to make the BRT an 'election issue'. ${ }^{67}$ A close aide in Shiela Dixit's office who monitors the press said in an interview that after much thought it was decided that the "song and

\footnotetext{
${ }^{63}$ Interview with Siddarth Pandey, October 4, 2010, New Delhi.

${ }^{64}$ An opinion poll carried out by NDTV on May 1st, 2008 reveals the class bias of the opposition to the project. While 65 per cent of the car drivers said that the BRT corridor made driving difficult, 75 per cent of the bus drivers disagreed.

${ }^{65}$ Narain, Sunita, “Editorial,” Down to Earth, March 1-15 (2010): 1.

${ }^{66}$ Ibid.

67 "No Fund Crunch for BRT Project: Delhi Govt," The Indian Express, October 16, 2008, accessed December 5, 2012. http://www.indianexpress.com/news/no-fund-crunchfor-brt-project-delhi-govt/374191.
} 
dance" ${ }^{\prime 8}$ about the BRT was being created by an elite media, which did not represent a vast section of the people. "The middle classes do not vote. The poor people who actually voted in the elections use buses. We decided to ignore the media's doom and gloom predictions," he said ${ }^{69}$. The predictions indeed turned out to be false and Sheila Dixit won a thumping victory. A media, divorced from ground realities, had egg on its face.

It would be simplistic to portray the media as 'lying' or 'misinformed'. Instead, it created a "regime of truth" 70 and started believing in it. Middle-class journalists with middle class visions writing for a middle-class audience found a convenient version of events, which suited 'everybody'. Democracy, or the 'republic of the streets' contested this version of events. ${ }^{71}$

\section{Conclusion}

In this essay, it has been argued that the present day environmental debates follow the structures of the development paradigm, a legacy of 20th century politics. A globalised economy has created a new middle class, who today has cornered the debate around environment, especially in the urban arena. Just as the North forced its own notion of development on the South, this middle class forces its own version of urban environmentalism onto the landscape and politics of Indian cities.

In seeking to establish this middle class environmentalism, this chapter briefly charted the course of development politics. Borrowing heavily from Wolfgang Sachs and Ernesto Escobar, it argued that development is a culturally situated concept that emerged in the aftermath of the Second World War from within the US. Resourceintensive and exploitative of scant natural resources, this singular development trajectory has led the world to a brink of a crisis from where there might be no return; the ever increasing hole in the ozone layer is leading to global warming, a rise in sea levels threaten to obliterate nations like Tuvalu and Maldives. Depleting forest covers, lack of agricultural land, scarcity of potable water have led to loss of

\footnotetext{
${ }^{68}$ Private interview with the author, Novermber 4, 2010.

${ }^{69}$ Ibid.

${ }^{70}$ Hall, Representation, 49-50.

${ }^{71}$ Joyce, Patrick, The Rule of Freedom: Liberalism and the Modern City (London: Verso, 2003).
} 
habitats, stratospheric rise in food prices and famines. That things have to change, that Development needs rethinking, was evident.

As the concern for our surroundings and the environment entered everyday discourse, it has been cornered by a transnational group of elites, themselves a product of economic development. This group drives the environmental discourse and directs it, marginalising other versions and voices. Taking urban environmentalism as a case in point and Delhi as the focus, two case studies in India were analysed. Through how a middle class media viewed and reported the two cases, both intending to lower vehicular pollution, the essay argued that the public sphere is cordoned off from a pluralistic debate and Baviskar's 'bourgeoise environmentalism' is shown as the only option. This is in stark contrast to the 'environmentalism of the poor' that the country's media had followed for two decades previous to the economic liberalisation. 